\title{
Logiczne aspekty języka (naturalnego)
}

\section{Logical aspects of (natural) language}

\author{
Anna Pietryga \\ INSTYTUT FILOZOFII, UNIWERSYTET OPOLSKI \\ PL. KOPERNIKA 11, 45-070, OPOLE \\ e-mail: apap@vp.p
}

\begin{abstract}
The paper consists of two parts. Part one presents a number of ambiguities the title of the volume conveys in each of its three Polish lexemes (which are rather similar to the ones used in the English version of the tile). The context of the Birthday leads the author to choose a meaning of the title and accept it as defining the area of further investigation.
\end{abstract}

Part two poses two main questions: 1) does natural language exist in a non - individual way? The answer suggested is it may exist as a result of an (free-will) compromise. Finally, part two addresses metalinguistic questions: a)is formal logic a specialized part of linguistics and b) may one present a methodological evaluation of formal works? Both of these are answered with a tentative yes.

Chcąc wypowiedzieć się na temat zadany tytułem naszego jubileuszowego tomu, autor staje przed wieloma pytaniami, na jakie zamierzony przez niego tekst zapewne odpowie. Autor może ich co prawda nie zauważyć, ale ponieważ odpowiednie rozstrzygnięcia mogą zapaść bez jego wiedzy i zgody, autor woli, w miarę swoich skromnych możliwości, spróbować sam. Pytania budzi już każdy z wyrazów tytułu, zwłaszcza jeśli wziąć pod uwagę drogę naukową Jubilata. Ponieważ możliwe jest udzielenie różnych odpowiedzi na pytanie, co w obecnym (wydawniczym) kontekście należy rozumieć przez logiczne aspekty języka, pozwolę sobie przedstawić jej kolejne przybliżenia. Część pierwsza wielokrotnie przywołuje publikacje profesora Jerzego Pogonowskiego (niektóre $\mathrm{z}$ nich ukazały się ponad dwadzieścia lat temu, czyli w poprzednim tysiącleciu). W części drugiej przypomina się niektóre z pytań zadanych przez Autora i proponuje się 
pewne rozwiązania niektórych. Mam nadzieję, że przedstawiony tekst, mimo jego niewątpliwych mankamentów, spotka się z wyrozumiałością Adresata.

\section{Wieloznaczności leksykalne związane z tytułem tomu}

\subsection{Logiczne}

\subsubsection{Rachunki logiczne}

Wieloznaczny jest wyraz logiczny, który może odnosić się do rozmaitych rachunków logicznych, takich jak np. klasyczny rachunek nazw, zdań czy predykatów, jak też do logik nieklasycznych, takich jak: logiki wielowartościowe (dopuszczające istnienie więcej niż dwóch wartości logicznych), modalne (dotyczące możliwości, konieczności oraz stanu faktycznego), deontyczne (dotyczące powinności), logika pytań i logika dialogowa (opisująca ludzkie rozmowy). We wciąż rozwijających się logikach nieklasycznych (i poza nimi) można napotkać pytanie, ile logika może/powinna dopuścić wartości logicznych i co one oznaczają ${ }^{1}$ oraz czym są kwantyfikatory (istnieją co najmniej dwa) ${ }^{2}$.

Do wspomnianych logik nieklasycznych należy też tzw. logika parakonsystentna, nie ulegająca przepełnieniu natychmiast po wystąpieniu sprzeczności wśród przetwarzanych danych 3 . Filozofowie nauki od dawna pytają o mechanizmy formułowania nowych hipotez. Przedstawiciele nauki ogólniejszej, za jaką można uważać logikę, również na swój sposób próbują naśladować procesy myślowe człowieka w nieoczekiwanych okolicznościach. Przykładem mogą być prace Charlesa Peirce’a na temat abdukcji. W poprzednim dziesięcioleciu Tim de Mey zauważył podobieństwa łączące niektóre odkrycia naukowe i eksperymenty myślowe $\mathrm{z}$ jednej, a zrozumienie dowcipu $-\mathrm{z}$ drugiej 4 . Co łączy te trzy rzeczy? Potrzeba znalezienia źródeł przyjmowanych dotychczas „oczywistości”, których zakwestionowanie może przyspieszyć zbudowanie nowej wersji opisu zdarzeń (do wyrażenia której brak nam niekiedy właściwego słownictwa 5). De Mey zauważa, że podobnie kształtuje się sytuacja w parakonsytentnych logikach adaptywnych, w których stosuje się tzw. backward chaining (czyli propagację wsteczną, by użyć określenia dotyczącego uczenia sieci neuronowych), która umożliwia wykrycie zależności pomiędzy pozornie niezwiązanymi elementami.

\subsubsection{Filozofia nauki w logice}

Do listy de Meya (odkrycia, eksperymenty, dowcip) osobiście dodałabym powieści kryminalne, w których osoby często (ale nie zawsze, co stanowi

1 Zob. Suszko 1976.

2 Zob. np. Murawski, Świrydowicz 2006:62-65.

3 Pietryga 2004.

4 Tim de Mey. 2005 Tales of the Unexpected. Logic and Logical Philosophy, vol.14, ss.69-88.

5 Zob. Pietryga 2007:215-216. 
dodatkowe utrudnienie) uciekają się do kłamstwa. Udzielanie fałszywej informacji jest zjawiskiem nierzadkim zarówno wśród ludzi jak i u innych organizmów, które chcą czasem przechytrzyć swojego przeciwnika, choćby poprzez przyjmowane barwy ochronne, które służą wysłaniu paradoksalnego komunikatu: „mnie tu nie ma” ${ }^{6}$. Człowiek dysponujący językiem naturalnym uprawia mimikrę upodabniając się do przedstawicieli grupy (z którymi chce, aby go identyfikowano), mówiąc ich językiem. Potrafi ponadto formułować paradoksy, z których dla logika szalenie ciekawym jest paradoks kłamcy - gdy ktoś mówi „teraz kłamię”. Paradoksy pozwalają nam czasami dobrze się bawić, ale dla badających przyczyny ich powstawania (meta)logików i metamatematyków stanowią prawdziwe wyzwanie zawodowe. Kiedy Kurtowi Goedlowi udało się dokonać arytmetyzacji składni oraz udowodnić dwa słynne twierdzenia dotyczące matematyki, stało się wiadome, że arytmetyka liczb naturalnych i systemy bogatsze od niej jeżeli są niesprzeczne, to są niezupełne (czyli dla pewnych zdań ani samo takie zdanie, ani jego negacja nie są twierdzeniami tej teorii.) Sytuacji tej nie zmieni w sposób istotny przyjęcie wybranego zdania (albo jego negacji) jako nowego aksjomatu, gdyż wówczas w badanej teorii pojawią się niechybnie następne nierozstrzygalne zdania. Nie można też dowieść niesprzeczności takiej teorii jej własnymi środkami. Tzw. zdanie Goedla to zapisany $\mathrm{w}$ języku formalnym paradoks kłamcy, pierwotnie wyrażony (jak wolno przypuszczać) w języku naturalnym. Ale przecież nie możemy powiedzieć, że język formalny wykorzystany przez Goedla jest językiem docelowym nauki formalnej ani że osiągnięcia Goedla są jej ostatnim słowem.

\subsubsection{Języki sztuczne}

Istnieje wiele języków sztucznych utworzonych na potrzeby konkretnych rachunków logicznych7 (te języki, chciałoby się powiedzieć, mają wyłącznie aspekty logiczne). Klasyczny Rachunek Nazw (KRN) posługuje się (do opisu relacji pomiędzy zakresami zbiorów niepustych) trzyliterowymi formulami, interpretowanymi jako zdania oznajmujące języka naturalnego. Wspomniane formuły występują $\mathrm{w}$ czterech odmianach pozwalając na opis 256 sylogizmów kategorycznych. Zmiana kaligrafii jest przy tym możliwa, ale właśnie kanoniczna forma zapisu ułatwia współpracę pomiędzy użytkownikami KRN. Jednocześnie dowolna formuła tego języka (np. SiP) nie należy wcale do języka używanego powszechnie i próżno by jej szukać w słownikach ogólnych języka polskiego. Z kolei Klasyczny Rachunek Zdań (KRZ) dotyczy zdań oznajmujących języka naturalnego (które zapisuje symbolami literowymi zgodnie z zasadami składni języka KRZ), ale nie dba się przy tym o ich znaczenie, lecz tylko o ich wartość logiczną, która jest funkcją wartości logicznych przypisanych zmiennym występującym w danej formule.

6 Być może jednak prawdą jest to, co napisał Robert Ardrey (a co mottem do swojej pracy uczynił Suszko 1976): „człowiek jest jedynym zwierzęciem, które potrafi okłamywać samego siebie”.

7 Zob. Pogonowski 2006:1. 


\subsubsection{Granice języków logiki}

Granice języków logiki są precyzyjnie wyznaczone w dziedzinie składni dla każdej z nich z osobna, podczas gdy uniwersa ich interpretacji są obierane każdorazowo niemalże dowolnie. $W$ naszych czasach reguły składni tych języków są zazwyczaj formułowane expressis verbis (w opisie definiującym). Językiem takim nazywa się dowolny zbiór symboli (rozdzielnie: funkcyjnych, stałych oraz relacyjnych) wraz z przypisaną każdemu z nich arnościa, która pozwala nie opisywać osobno składni jako takiej. Istnieją wszakże takie formuly, które nie należą do żadnego z języków logiki, a przynajmniej nie do tego języka, do którego niektórzy użytkownicy języka naturalnego chcieliby je przypisać. Mam na myśli nowatorskie zapożyczenia typu ØSiP, pomieszczone $\mathrm{w}$ jednym $\mathrm{z}$ internetowych podręczników, chwalonym przez niektórych czytelników za jego użyteczność. Bezsporny ów pożytek wynika z braku wyraźnie określonych granic języka naturalnego, który dopuszcza (na swoim własnym terenie) hybrydyzację języków logiki.

\subsubsection{Przymiotnik logiczny}

Polski przymiotnik logiczny może również odnosić się do części gramatyki języka naturalnego, zajmujących się rozbiorem logicznym zdania, w którym wskazuje się wewnętrzne zależności pomiędzy tworzącymi to zdanie jednostkami leksykalnymi lub wskazujących jego podmiot logiczny (nazwy tej używano w tzw. gramatyce tradycyjnej języka polskiego dla określenia podmiotu, który występuje w formie wyznaczonej przez składnię zdania, jak np. w zdaniu wody przybywało). Słownik wyrazów obcych wymienia również połączenie wyrazowe pamięć logiczna, oznaczające pamięć wykorzystującą zrozumienie zdarzeń w celu dokonania ich rekonstrukcji. Znaczenia potoczne tego terminu to: poprawnie myślacy, sensowny, rozsądny i konsekwentny ${ }^{8}$.

\subsection{Aspekty}

\subsubsection{Aspekt gramatyczny}

Dość zawikłane w podobne wieloznaczności jest również słowo aspekt, dla językoznawcy oznaczające kategorię gramatyczną czasownika, która wyraża jego dokonaność/niedokonaność i jest związana ze sposobami wyrażania czasu gramatycznego $\mathrm{w}$ poszczególnych językach. Za logiczne aspekty języka naturalnego można byłoby uznać wszystkie te jego aspekty, które logicy zdołali już sportretować w języku którejś z logik. Kiedy już wszyscy wiemy, czym jest aspekt $w$ języku polskim i że przypomina on pod pewnymi względami lacińskie perfectum, stajemy przed ostatnią drobną trudnością, jaką jest ustalenie aspektu czasownika być, który posiada czas teraźniejszy formalnie tożsamy z przyszłym prostym (będę, tak jak kupię), co każe przypuszczać, że mamy do czynienia z czasownikiem dokonanym, lecz jednocześnie tworzy imiesłów przymiotnikowy czynny (będący, tak jak 
kupujacy) oraz przysłówkowy współczesny (będąc, tak jak kupujac) jak czasowniki niedokonane. Wcześniejsze wersje gramatyki języka polskiego przyjmowały istnienie większej liczby rozróżnień, wskazując np. tzw. czynności jednokrotne i wielokrotne (walnać i walić). Nagórko przyznaje, że wyrazy „nieregularne” są nieodzowne w codziennej komunikacji i że polski czasownik być oraz jego odpowiedniki w innych językach są tego przykładem 9.

\subsubsection{Logika temporalna}

Podobnie jak współcześni poloniści, także i logicy (już od starożytności) rozważają połączenia logiczne pomiędzy zdaniami opisującymi czynność zakończoną i taką, o której wiemy zaledwie, że ją rozpoczęto. Pionierem w podejmowaniu prób budowania systemów logiki, w których można byłoby sformułować rozumowania uwzględniające aspekt czasownika, w jakim występują orzeczenia przesłanek i wniosku (np. zaorat, więc orat lub orat, więc zaorat) zapoczątkowal Diodor Chronus. Dalszy rozwój tej tzw. logiki temporalnej przypada na wiek XX ${ }^{10}$. Rozwinięto w niej, poza analizą czasów gramatycznych, kwestie dotyczące determinizmu oraz orzekania tożsamości przy zmianie następującej w czasie. Co więcej, rozważa się samą naturę czasu i sposób jego pojmowania ${ }^{11}$.

\subsubsection{Plusquamperfectum w logice adaptywnej}

Wspomniana wcześniej (1.1) logika adaptywna zakłada, że wszystkie jej formuły zachowują się poprawnie, „o ile i dopóki” ich kartoteka jest czysta, tzn. w prowadzonych dowodach brak adnotacji dotyczącej wcześniejszego pojawienia się danej formuły zarówno $\mathrm{w}$ postaci zanegowanej, jak i niezaprzeczonej (wystąpienie takie nazywa się złym zachowaniem danej formuły). Zachowanie poprawne danej formuły jest więc w pewnym sensie zaprzeczonym perfectum (aspekt dokonany): nie jest tak, jakoby formuła się była zachowała źle ${ }^{12}$.

Wspomniany w 1.1.1 Tim de Mey przywołuje nazwiska odkrywców, którzy potrafili zmienić paradygmat przyjęty przez naukę im współczesną, proponując jej nowe prawa. Przypomina postacie Galileo, Lavoisiera, a także Williama Harvey'a z jego rewolucyjną teorią dotyczącą krążenia krwi, do akceptacji której potrafil przekonać swoje nowoczesne otoczenie już w trzydzieści lat. De Mey stwierdza, ze próby opisania procesu odkrycia naukowego przez Thomasa Kuhna napotykały sprzeciw samego Kuhna, niechętnego ograniczaniu stosowalności dotychczas przyjmowanych pojęć w niektórych okolicznościach ${ }^{13}$.

\footnotetext{
9 Nagórko 1996:88 i 118.

10 Zob. np. Jarmużek 2006, Marciszewski 1987:318.

11 Zob. np. opracowanie Indrzejczaka: www.filozof.uni.lodz.pl/prac/ai/Tense.pdf .

12 Pietryga 2004:56-71. Nawiasem mówiąc, przy okazji rozważań gramatycznych nad logiką adaptywną wart zbadania jest aspekt czasownika sum, esse, fui w języku łacińskim.

13 Tim de Mey 2005:81-82.
} 


\subsection{Języka}

\subsubsection{Liczba języków}

Także i wyraz język jest wielce kłopotliwy, ze względu na liczbę istniejących języków, nawet jeżeli przyjmiemy, że interesują nas „zaledwie” języki naturalne. Pogonowski, pisząc o ich liczbie, podaje pięć wersji odpowiedzi na pytanie „ile jest języków”: rozpiętość rozwiązań sięga od jednego do continuum, czyli liczby podzbiorów zbioru liczb naturalnych ${ }^{14}$. Granica dolna przyjmowanej liczebności języków świata wynosi jeden. „Odpowiedź taka zakłada, że potrafimy skonstruować teorię lingwistyczną, której jedynym zamierzonym modelem jest Język Naturalny. Znane twierdzenia logiczne (twierdzenie Goedla, twierdzenie LoewenheimaSkolema) ukazują pewne ograniczenia, jeśli chodzi o istnienie takiego (z dokładnością do izomorfizmu) modelu. Jednak odpowiedź taka jest obiektem pożądania zarówno niektórych lingwistów jak i filozofów. Taka ich liczba przyjmowana jest również, co zauważa Tarski5, na przykład przez osoby zakładające, że język, który chcą opisać, ma te same własności co język, w jakim chcą go opisać. Przypuszczalnie Tarski miał na myśli osoby, które nie uświadamiają sobie istnienia metajęzyka, natomiast jego wypowiedź przypomina boje gramatyków o dopasowanie gramatyk języków europejskich do wzorców starożytnych, boje przeniesione później na inne kontynenty.

\subsubsection{Opis parole}

Istnieją lingwiści, których zdaniem język należałoby opisać nie jako abstrakcyjny system (langue)(o której w gramatyce szkolnej), lecz jako dźwięki i napisy stanowiące wypowiedzenia rodzimego użytkownika danego języka (parole). Niektórzy logicy i matematycy postulując zarys teorii systemu językowego, uznają poszczególne słowa-okazy (lub morfemy) za podstawowe jednostki języka. Niektórzy zamierzają opisać relacje lączące segmenty wypowiedzi za pomocą parametrów semantycznych, zaznaczając, iż „[w]ydzielenie segmentów i łączących je zależności jest jednoczesne: zakładają się one wzajemnie”. Każdemu okazowi przyporządkowana ma zostać wiązka jego znaczeń składowych, które ten wyraz zawiera lub do której to wiązki dany wyraz zostaje zaliczony. Takie podejście do badania języka (jako skończonych ciągów morfemów) sprzyja zdaniem Pogonowskiego dopuszczeniu tezy o istnieniu kontinuum języków świata.

\subsubsection{Continuum}

Jedynym mankamentem, jaki autor żartem dostrzega $\mathrm{w}$ takim rozwiązaniu, jest zbyt obszerny Uniwersalny Indeks Języków. Jednocześnie wyniki badań prowadzonych przez niektórych etnologów zdają się potwierdzać ich tezę, że „wyizolowane słowa są jedynie 
wymysłami lingwistycznymi”. Lektura Dzieł Bronisława Malinowskiego, zwolennika tej tezy, uzmysławia, że „moja ziemia” to może jedynie fragment poletka, który mam prawo uprawiać wraz z innymi członkami szeroko pojętej rodziny i zbierać wydany z niego plon w określonej porze roku. „Prawo uprawiania ogrodów przysługuje klanowi. Każdy klan uprawia swoje ogrody wspólnie (sic!) w obrębie jednego ogrodzenia i każdy klan posiada swoje własne terytorium, na którym uprawia swój ogród z wyłączeniem innego klanu”. Dla badacza systemu posiadania ziemi ważne jest to, jak ,jest ona wykorzystywana i dlaczego posiada wartość”. Dotyczy to praw do określonej części ziemi przysługujących zarówno jednostkom, jak i grupom społecznym ${ }^{16}$. Dla badacza języka ważne jest, aby wziąć pod uwagę różnice kulturowe modyfikujące znaczenie „pojedynczych” wyrazów.

Jak widać, opis parole wiąże się ze specyficznymi utrudnieniami. Po pierwsze, jeśli próbujemy ją opisać nie stosując uogólnień, otrzymujemy rezultat lokalnie co prawda interesujący, ale globalnie stanowczo zbyt obszerny. Po drugie, opis taki, aby był subiektywnie komunikowalny, potrzebuje powszechnie zrozumiałych liter i terminów, a te ofiarowuje nam gramatyka już od szkolnych lat. Między innymi dlatego pozwoliłam sobie nimi właśnie się posłużyć.

\subsubsection{Nieodzowne uproszczenia}

Kolejne pokolenia polonistów biedzą się, próbując opisać język polski i nadać normy temu narzędziu, które znamy jako użytkownicy tak dobrze, że możemy go nawet nie zauważać. Badacze języka naturalnego konstruują i poprawiają teorie naukowe, które mają stanowić opis systemu konkretnej langue, rozumianej jako abstrakt, lub nawet całego zbioru takich systemów. To samo dotyczy również leksykonów badanych języków: doświadczeni leksykografowie celowo nie wprowadzają przy tym niektórych zauważanych neologizmów do periodycznie wznawianych słowników ogólnych, gdyż znana im jest wysoka przemijalność tych nowinek ${ }^{17}$. Do uproszczeń stosowanych w kwestii opisu języka naturalnego należy między innymi niedostrzegana na początku poznawania nauki o języku (jak i logiki) kwestia braku definicji zdania oznajmującego w języku naturalnym (kwestię tę, wraz z pytaniem o to, jakim obiektom logik może przypisywać prawdziwość, śmiało i pracowicie podjął Alfred Tarski). Podejście filologiczne ma własne cele, niekoniecznie zbieżne z celami przyświecającymi logikom. Student pierwszego roku wydziału filologicznego bywa zaskoczony informacją o braku definicji zdania w jego języku ojczystym. Zna on przecież rozmaite jego tryby, a samodzielnie podane przykłady gramatyczne tłumaczy na inne języki naturalne, z chęcią również podejmuje próby formalnego zapisu koniunkcji oraz implikacji dwóch takich zdań. Język naturalny, który słyszymy i widzimy na co dzień, potrafi przy tym wchłonąć nawet hybrydy lączące w sobie elementy grafii

16 Malinowski 1987a:475.

17 Zob. Lotko 2009. 
dwóch różnych języków logicznych i posługiwać się nimi dla złagodzenia „oporu materii” przy wysiłku intelektualnym, jakim jest nauka logiki.

Podobne uproszczenia występują na granicy języka naturalnego i logiki niejednokrotnie. Przykładem może być spójnik implikacji materialnej stosowany dla zapisu wnioskowań dedukcyjnych, mimo że przypisana mu funkcja prawdziwościowa nie zgadza się $\mathrm{z}$ intuicjami rodzimych użytkowników języka naturalnego dotyczącymi tychże wnioskowań. Wśród komentarzy dotyczących tej kwestii należy wymienić spostrzeżenie Kazimierza Ajdukiewicza, dotyczące okresu warunkowego. Jego zdaniem wyraża on niewiedzę mówiącego co do ewentualnej fałszywości poprzednika i ewentualnej prawdziwości następnika oraz gotowość do przeprowadzenia odpowiedniego wnioskowania18. Co ciekawe, wiele lat po tym, jak dokonano wspomnianego uproszczenia, niektórzy uczeni rozważają kwestę (nie)logiczności języka naturalnego, niektórzy zaś podejmują próbę rozwikłania powstałego nieporozumienia ${ }^{19}$. Zatem przynajmniej część logiki można uważać za precyzyjnie obmyślony rezultat nieprecyzyjnej imitacji języka naturalnego i zarazem za (nieco krzywe) odbicie tego ostatniego ${ }^{20}$. Pogonowski, pisząc o granicach między lingwistyką formalną (zaliczaną do językoznawstwa) a matematyczną (dyscyplina matematyczna), przede wszystkim zauważa płynność tych granic i wspólny wymienionym dyscyplinom aparat pojęciowy (logiki symbolicznej i matematyki). Za podstawową różnicę między rozważanymi dyscyplinami uważa zaś fakt, iż lingwistyka matematyczna, w przeciwieństwie do formalnej, nie zajmuje się językiem naturalnym. Obydwa rodzaje lingwistyki pretendują do miana teoretycznego zaplecza językoznawstwa, bynajmniej nie roszcząc sobie w tej kwestii prawa do wyłączności ${ }^{21}$.

\section{3•3. Wymieranie języków}

Wielu z nas żyjących na Ziemi słyszało o językach wymarłych i niektórzy z nas są skłonni uważać, że tych języków już nie ma ${ }^{22}$. Prognozy donoszą, że $\mathrm{w}$ ciągu najbliższych dwudziestu lat zniknie ponad połowa będących dziś w użyciu języków23 (czyli umrą władający nimi ludzie). Pisząca te słowa wciąż nie rozumie, jakie argumenty przemawiają za uznaniem języków martwych za nieistniejące - oprócz wygody opisującego (podobne względy każą autorom niektórych podręczników logiki wykluczać osoby martwe spośród desygnatów przysługującym im nazw ogólnych). Tymczasem za istnieniem tych języków przemawiają udane próby odczytania starych znaków czy nawet wskrzeszenia martwego języka (np. hebrajskiego). Dość ciekawe jest również to, że pozornie martwa lacina posiada (dzięki staraniom

\footnotetext{
18 Zob. Wojtasiewicz 1972, Ajdukiewicz 1985, Pelc 1986.

19 Stanosz 1999

20 Pogonowski 1991: 14 pisząc o relacji między językiem naturalnym i sztucznymi systemami logiki formalnej używa określenia „sprężenie zwrotne".

21 Pogonowski 1991:13,16.

22Zob. np. hasło „języki martwe” w internetowym słowniku języka polskiego www.sjp.pwn.pl.

23 Pogonowski20o6:§2.
} 
Watykanu w tej kwestii) wciąż aktualizowany zasób słów, a jej znajomość (niezależnie od polityki) ułatwia poznawanie wielu języków romańskich. Warte przytoczenia ku pociesze zasmuconych tym spostrzeżeniem są słowa Jensa Jespersena, cytowane przez Malinowskiego: „[...] typowy filolog, który głęboko wierzy $\mathrm{w}$ to, ze język staje się rzeczywiście piękny $\mathrm{i}$ pouczający (...) gdy staje się językiem martwym, wypaczył studia lingwistyczne w sposób tak znaczny, że nikt z nas nigdy nie wyleczył się w pełni z urazu porodowego jego kategorii gramatycznych". Malinowski przytacza też następujące słowa Jensa Jespersena: „Tradycyjny gramatyk starej daty ustala reguły, a odstępstwa od nich interpretuje jako błędy, które według niego w sposób uprawniony można określić jako nielogiczne"24. Podobnie bronili roli kontekstu Wittgenstein i cytowany przez niego Frege ${ }^{25}$.

\section{Czy język naturalny istnieje?}

\subsection{Mowa egocentryczna}

Kiedy niemowlę zaczyna się uczyć porozumiewania ze swoim otoczeniem, rozwija własny idiolekt i na ogół wyrasta na użytkownika języka, którym mówią osoby z jego otoczenia. Trudno się nie zgodzić, że każdy z nas rozwija swój własny idiolekt odbierając i formułując komunikaty werbalne słyszane w otaczającym go środowisku. Język osobniczy w toku rozwoju przechodzi przez rozmaite fazy, z których wczesne nazywane są fazami mowy egocentrycznej. W tej fazie dziecko używa mowy jako środka ekspresji (podobnie jak w analogicznej fazie rozwoju jego twórczości plastycznej, podczas której dziecko nie dba o opinię otoczenia ani o zrozumienie swoich intencji). Mowa egocentryczna stopniowo zanika ustępując miejsca używaniu języka jako środka komunikacji. Osesek, w sprzyjających okolicznościach, nie potrzebuje jeszcze dbać o bycie zrozumiałym. Przyjazne otoczenie stara się odgadywać jego potrzeby. Starsze dziecko zazwyczaj samo chce się uczyć mówić (wybierać, czy czegoś chce, czy nie, i czego mianowicie) i znajduje swoje miejsce w grupie. Wtedy uczy się używać języka (języków), jakim(i) posługuje się jego otoczenie. Robi to we własnym interesie. Znajomość języka pomaga w zabawie i w utrzymywaniu więzi rodzinnych i przyjacielskich, pomaga też podsłuchać lub zmylić przeciwnika, jeżeli sytuacja tego wymaga. Nauka języków obcych, która bywa obowiązkiem domowym lub szkolnym, w okolicznościach niesprzyjających bywa też kwestią życia i śmierci.

\subsection{Geopolityka}

W ostatnich latach mogliśmy obserwować zmiany na liście języków Europy, z której zniknęły niektóre z języków „narodowych”. Okazały się one przypisane nie jednemu, lecz kilku narodom, przy czym narody te $\mathrm{z}$

24 Malinowski 1987b:21 i 20.

25 Wittgenstein 1972:39. 
jakichś powodów nie chciały już być jednym narodem ${ }^{26}$. Słyszymy również o tym, że ktoś nagle przestał rozumieć język, którym władał dotąd biegle, i że uniemożliwia mu to rozmowę $\mathrm{z}$ przeciwnikiem politycznym. Trudno zaprzeczyć istnieniu zależności, jaka łączy istnienie języka naturalnego z geopolityką i rozwojem cywilizacji (i jakie zapożyczenia zostały przez użytkownika języka całkowicie zasymilowane we własnym interesie).

Język potoczny (zwany czasami również naturalnym lub narodowym), podobnie jak idiolekt niemowlęcia, zapożycza rozmaite elementy (z akcentem wyrazowym włącznie) od innych języków potocznych lub od innych własnych dialektów (tzw. zapożyczenia wewnętrzne). Specjaliści opisują to zjawisko w licznych publikacjach, uwzględniając również stopień asymilacji tych zapożyczeń ${ }^{27}$. Wysiłki polonistów można uznać za próbę uchwycenia i utrwalenia jednej polszczyzny, którą zresztą posługuje się (poza pewnymi wyjątkami) również polskie radio, prasa i telewizja; wysiłki te sprzyjają stopniowemu zanikaniu etnicznej różnorodności językowej. Jednocześnie możemy obserwować, jak zmienia się obowiązujący dialekt mazowiecki, który stanowi w Rzeczypospolitej odpowiednik Received Pronunciation (RP) ze Zjednoczonego Królestwa. RP jest językiem, którym posługują się wykształceni Brytyjczycy. Język ten pozwala im nie ujawniać szczegółów terytorialnych swojego pochodzenia. Człowiek mówiący RP jest w pewnym sensie człowiekiem znikąd.

\subsection{Czy istnieje ponadjednostkowy język naturalny?}

Można zaproponować tezę, że idiolekty, którymi władamy, to jedyne istniejące języki ludzkie. Jednostkowy użytkownik języka może mieć do dyspozycji więcej niż jeden wariant (dialekt) języka ogólnego. Warianty te może on wykorzystywać na przykład po to, żeby odpowiedzieć na pytanie zadane w danym dialekcie. Jeżeli przyjąć, że uczymy się języka od innych ludzi (rodziców, sąsiadów, nauczycieli) ${ }^{28}$, którzy każdorazowo wspólnie z nami wyznaczają płaszczyznę językową dialogu (czyli dialekt, w którym rozmawiamy), można również przyjąć, że dialektów znamy co najmniej tyle, ile prowadzimy rozmów. Czynnik zmiany każe uwzględniać nie tylko różnice pomiędzy rozmówcami, ale również zmiany (diachronicznej) naszego własnego idiolektu. Continuum daje nam możliwość wybrania takiej klasyfikacji, która posłuży naszym celom badawczym. Takie postawienie sprawy ma wyjątkową zaletę: język osobniczy można nagrywać, czego nie można powiedzieć o ,języku rozumianym jako abstrakt”. Pogonowski zauważa, że matematyczne opisy języków zazwyczaj rozpatrują je jako twory statyczne (czyli synchroniczne) i zarazem „całkowicie określone" 29 , co wydaje mi się nie do pogodzenia $\mathrm{z}$

\footnotetext{
26 Zob. np. Katarzyna Knapik: „Mikrojęzyki południowosłowiańskie: język czarnogórski, bośniacki, dialekt rezjański”, http://kns.uni.lodz.pl , Maria Borownicka 1995:54

27 Zob. np. Klemensiewicz 1974:35-63, Brueckner 1974:73-106.

28 Por. Pogonowski 2006:\$3.

29 Pogonowski 2006, §4.
} 
przyjmowaniem morfów-okazów za podstawowe jednostki języka. Ale to właśnie dzięki przyjętym uproszczeniom można w ogóle konstruować teorię języka ogólnego, a dzięki niej - porównywać idiolekty, korzystając z jej aparatu pojęciowego.

W końcu trzeba postawić nieuchronne a niebezpieczne pytanie: czy język naturalny istnieje, a jeśli tak, to czym jest. Autor pracy „Ile jest języków” przyznaje, że trudno sformułować w tej kwestii jednoznaczną definicję („ogranicza” on przy tym swoje zainteresowania do badań języków istniejących, możliwych oraz branych in abstracto, jako pewne typy systemów semiotycznych) ${ }^{30}$. Zagadnienie to rozważa w pierwszym paragrafie wspomnianego tekstu, przyznając, że języki naturalne są „Żywymi systemami semiotycznymi, zmiennymi w czasie, uwarunkowanymi społecznie, których pierwszoplanowe funkcje komunikacyjne mają charakter pragmatyczny". Od tych czynników opis matematyczny języków naturalnych zazwyczaj abstrahuje, „nie ma jednak zakazu wstępu" na te tereny badawcze dla matematyków i logików31). Z kolei autor innej pracy ${ }^{2}$ nie widzi powodu, dla którego wkład logików i matematyków do opisu języków naturalnych miałby być gorszy niż wkład pracujących $w$ tej dziedzinie językoznawców. Zapewne, każdy ma swoje własne sposoby walki, które bywają nieznane sprzymierzeńcom z innych dziedzin. Pragnę zasugerować odpowiedź dla lingwisty niewygodną: język naturalny istnieje o tyle tylko, o ile dopasowujemy się komunikacyjnie do innych ludzi, co nie zawsze jest sprawą zewnętrznego przymusu. Zamiast próbować oddzielić swoje idiolekty, możemy mówić, za Wittgensteinem, o „nieprzerwanym zachodzeniu na siebie włókien”33.

\subsection{Metapytania lingwistyczne}

Będąc rodzimym użytkownikiem języka i lingwistą zarazem, pragnę ustosunkować się do dwóch spośród pytań, zadanych w jednym $\mathrm{z}$ cytowanych tekstów 34:

a) czy logika formalna (lub jej podstawowa część) jest wyspecjalizowanym działem językoznawstwa?

b) czy ze strony językoznawstwa możliwa jest jakaś metodologiczna ocena podejścia formalnego?

Otóż wydaje mi się, że na obydwa te (nie całkiem jednoznacznie sformułowane) pytania można odpowiedzieć twierdząco. W pierwszym przypadku odpowiedzi takiej sprzyja wspomniane wyżej rozumienie języka jako zbioru obiektów fizycznych, będących dźwiękowymi lub graficznymi

\footnotetext{
30 Pogonowski 2006, §1.

31 Pogonowski 2010:\$6A. Dodajmy, że wstępna wersja ubiegłorocznego artykułu poświęconego „Niewyrażalnej tęsknocie za modelem zamierzonym”, która traktuje o podstawach matematyki i w której autor wyraźnie stwierdza, że nie będzie „odnosić się do problematyki metodologicznej dotyczącej modeli zamierzonych w naukach empirycznych i humanistyce” przedstawia intrygujące fakty dotyczące pragmatycznych aspektów logiki przy wskazywaniu wybranego modelu jako zamierzonego. Pogonowski przywołuje w swojej pracy fragmenty Epistemologii Jana Woleńskiego.

32 Pogonowski 2006:§1.

33 Wittgenstein 1972:§67.

34 Pogonowski 1999.
} 
realizacjami wypowiedzi sformułowanych w tym języku; należy przy tym uznać, że wąska specjalizacja logiki formalnej nie pozwala na stosowanie jej do wszystkich celów osiąganych w nauce o języku. $\mathrm{Z}$ mniejszą ochotą zgodzę się natomiast na twierdzenie, jakoby struktura relacyjna, o indywidualnej sygnaturze, stanowiła model zamierzony dla branej pod uwagę teorii lingwistycznej35 sformułowanej przez lingwistę. Tęsknota za modelem zamierzonym jest zrozumiała, ale nie każdy językoznawca zgodzi się od razu (a może i wcale?), że dokładnie opisana struktura jest tym samym, co zamierzony przedmiot jego badań.

Jeżeli chodzi o pytanie drugie - ocena podejścia formalnego jest możliwa, gdyż może dotyczyć tendencyjnego doboru próbek językowych ${ }^{36}$ lub braku znajomości literatury przedmiotu37 a nawet wewnętrznych sprzeczności proponowanej teorii formalnej38. Może jednak również mieć wydźwięk pozytywny, wyrażając wdzięczność umysłom ścisłym (także językoznawcom) za dokonanie opisu fonologicznego języka naturalnego i za wytrwałe próby uporządkowania „kompletnego chaosu” wypowiedzi początkujących adeptów językoznawstwa39. Osobiście nie uważam digitalizacji za czynność przeciwną ludzkiej naturze, skoro nawet najwybitniejsi Artyści słyszą i widzą tylko różnice przekraczające próg ludzkiej percepcji. $\mathrm{Z}$ drugiej strony zgadzam się $\mathrm{z}$ poglądem Jana Łukasiewicza, że logika symboliczna wymaga pracy zbyt suchej i nudnej dla umysłów tęskniących za absolutem40.

Jest również trzecie pytanie zadane przez Jubilata $\mathrm{w}$ tekście poświęconym liczbie języków naturalnych: co „widzi” lingwista, czytając prace z lingwistyki formalnej? Odpowiedź, cokolwiek krotochwilna, brzmi: lingwista woli słuchać, aby Poznać, skąd pochodzi prelegent i gdzie skończył studia.

\section{Zakończenie}

Nie zdołam w tym krótkim tekście ani rozstrzygnąć, czy istnieje ponadjednostkowy język naturalny, którego logiczne aspekty należałoby opisać, ani też napisać, czy takie rozstrzygnięcie jest w ogóle możliwe. Faktem pozostaje, że przekonanie o jego istnieniu pozwoliło nam wszystkim się spotkać (w wariancie wymowy Krakowsko-Poznańskiej).

Plurimos Annos, Panie Profesorze.

\footnotetext{
35 Pogonowski 2006, §7.

36 Pietryga 2006b.

37 Pietryga 2004:114.

38 Pietryga 2006a.

39 Zob. np. Anna Luchowska (niedatowany niepublikowany maszynopis) Poznań: UAM.

40 Łukasiewicz 1987:184.
} 


\section{Anna Pietryga: Logiczne aspekty języka (naturalnego)}

\section{BIBLIOGRAFIA}

Bobrownicka, M. 1995. Narkotyk mitu. Szkice o świadomości narodowej i kulturowej Słowian zachodnich i południowych. Kraków: Universitas.

Bruecknar, A. 1974. Początki i rozwój języka polskiego. Warszawa: PWN.

De Mey, T. 2005. Tales of the unexpected,[w:] Logic and Logical Philosophy vol.14, ss. 69-88.

Indrzejczak, A. 2005. Logika i czas: wprowadzenie do logik temporalnych. www.filozof.uni.lodz.pl/prac/ai/Tense.pdf

Jarmużek, T. 2006. „Rekonstrukcje rozumowania Diodora Kronosa w ontologii czasu punktowego" [w:] Analiza i Egzystencja, t.3. ss.197-215. Szczecin: WN Uniwersytetu Szczecińskiego.

Klemensiewicz, Z. 1974. Historia języka polskiego. Warszawa: PWN.

Katarzyna, K. 2007 „Mikrojęzyki południowosłowiańskie: język czarnogórski, bośniacki, dialekt rezjański”. http://kns.uni.lodz.pl

Lotko, E. 2009. Sravnavàcíi a bohemistické Ajdukiewicz, Kazimierz, 1985. „Okres warunkowy a implikacja materialna" [w:] tenże, Język a poznanie, t.2. Warszawa: PWN, ss. 248-265.studie. Olomouc.

Malinowski, B. 1987. Dzieła. Ogrody koralowe i ich magia, t. 4 część 2. Warszawa: PWN

Malinowski, B. 1987. Dzieła. Ogrody koralowe i ich magia, tom 5. Warszawa: PWN

Marciszewski, W. 1988. Mała encyklopedia logiki. Wrocław: Ossolineum.

Murawski, R., Świrydowicz, K. 2006. Podstawy logiki i teorii mnogości.

Pelc, J. 1986. „Jeżeli, to”. Studia Semiotyczne XIV-XV, ss. 271-286.

Pietryga, Anna, 2004. Status zasady sprzeczności w świetle logiki współczesnej. Kraków: Aureus.

Pietryga, A. 2006. "Two kinds of unexpected problems in writings on logic", Logic and Logical Philosophy, vol. 15 nr 2, ss. 155-162.

Pietryga, A. 2006. "Tarski's T-scheme as an alleged basis of Montague semantics", Logic and Logical Philosophy, vol. 15 nr 4, ss. 369-379.

Pietryga, A. 2007. "O leksykologicznych aspektach 'logiki komplementarności", [w:] Studia Semiotyczne XXVI, s.209-217.

Piękosz, A. 2008. Wstęp do teorii modeli. Kraków: Politechnika Krakowska.

Pogonowski, J. 1988. Combinatory semantics: a contribution to the metatheory of linguistics. Poznań: UAM.

Pogonowski, J. 1991. Hierarchiczne analizy języka. Poznań: Wydawnictwo naukowe UAM.

Pogonowski, J. 1999. „Dialog czy sprzeczka?” [w:] Dyskurs naukowy: tradycja i zmiana, St. Gajda (red.), ss. 97-101. Opole: Uniwersytet Opolski - Instytut Filologii Polskiej.

Pogonowski, J. 2006. "How many languages exist?" [w:] Investigationes Lingvisticae, vol. XIII, ss. 1-12. Poznań: UAM.

Pogonowski, J. 2010. „Niewyrażalna tęsknota za modelem zamierzonym”. Tekst odczytu wygłoszonego 10 czerwca 2010 na spotkaniu Grupy Logiki, Języka i Informacji w Uniwersytecie Opolskim.

Smart-Stevens, M. 1972. Children: Development and Relations. New York The Macmillan Company.

Stanosz, B. 1999. „O pojęciu języka prelogicznego”, ss. 215-222. Warszawa: Biblioteka Myśli Semiotycznej. 
Suszko, R. 1976. „The Fregean axiom and Polish mathematical logic in the XXs”. Studia Logica XXXVI, no 4, ss. 377-380.

Tarski, Alfred, 1995. Pisma logiczno-filozoficzne. Tom I: Prawda. Warszawa: WN PWN.

Tokarski, J. 1980. Słownik wyrazów obcych. Warszawa: PWN.

Wieczorek, K., A. 2002. wieczorek-logika_dla_opornych.pdf

Wittgenstein, L. 1979. Dociekania filozoficzne. Warszawa: PWN.

Wojtasiewicz, O., A. 1972 „Formalna i semantyczna analiza polskich spójników”, [w:] Studia Semiotyczne III, Warszawa: PAN, ss.109-144.

Woleński, J. 2005. Epistemologia. Warszawa: WN PWN. 